\title{
Does Ethical Orientation of HRM Impact on Employee Ethical Attitude and Behavior? Evidence from Sri Lankan Commercial Banks
}

\author{
Viruli A. de Silva ${ }^{1}$, H. H. D. N. P. Opatha ${ }^{1}$, Aruna S. Gamage ${ }^{1}$ \\ ${ }^{1}$ Department of Human Resource Management, University of Sri Jayewardenepura, Sri Lanka \\ Correspondence: Viruli A. de Silva, Department of Human Resource Management, University of Sri \\ Jayewardenepura, Sri Lanka.
}

Received: November 27, 2017

Accepted: December 21, 2017 Online Published: December 27, 2017

doi:10.5539/ibr.v11n1p217

URL: https://doi.org/10.5539/ibr.v11n1p217

\begin{abstract}
Employee ethical behavior (EB) has been recognized as the behavior that organizations pursue to drive performance and success. Despite many positive consequences of EB, corrupt business practices and unethical behavior are common in organizations. How Ethical Orientation of Human Resource Management (EOHRM) or ethical criteria embedded HRM functions directed as a 'bundle' could address this problem has not been empirically tested in research. This study examined how EOHRM could influence employee EB in organizations through an identified mediator employee Ethical Attitude (EA). A three-construct integrated model was developed based on literature gaps and tested empirically. The type of investigation was correlational, cross-sectional in the time horizon and unit of analysis was individual. A stratified random sample of 550 senior and middle-level managers was selected from 11 domestic Licensed Commercial Banks (LCBs) in Sri Lanka. A pre-tested structured questionnaire (with 5-point Likert Scale) was used to collect primary data. Using SPSS Version 23.0, correlation and regression analysis were performed on 360 usable responses (65\%). EOHRM was positively and significantly related to employee EA $(0.432, p<.001)$ and EB $(0.494, p<.001)$. Employee EA partially mediated $(0.269, \mathrm{p}<.001)$ the relationship between EOHRM and EB. Results were consistent with the theoretically derived four hypotheses, establishing that EOHRM, or ethical criteria embedded HRM functions directed as a bundle will increase employee EA and EB at work. Theoretical and managerial implications of the findings and directions for further research are discussed.
\end{abstract}

Keywords: ethical orientation of HRM, ethical behavior, ethical attitude, organizations, commercial banks

\section{Introduction}

Organizations pursue to drive performance and success through Employee ethical behavior (Askew, Beisler \& Keel, 2015; Dessler, 2013; Opatha, 2015). Employee ethical behavior (EB) has been referred to as the study of ethical and unethical decision-making and behavior in an organization, especially in a work context (Trevino, Nieuwenboer \& Kish-Gephart, 2014, p. 6.1). Trevino and colleagues also stated that behavioral ethics or organizational ethics based research is the systematic study of ethical/unethical behavior of employees in organizations. The 'individual' is important in organizations as people bring to the workplace their own perceptions about what is ethically right or wrong (Dessler, 2013). The risk to the organization is that 'good' people can be morally blind and engage in unethical behavior, without knowing the immoral nature of their actions (Kish-Gephart, Harrison \& Trevino, 2010). The shared perception of what is correct behavior and how an ethical dilemma should be handled has been referred to as the 'ethical climate' in an organization (Victor \& Cullen, 1988). Researchers have identified that ethical climate promotes employee EB, and also influences many individual and organizational level work-related consequences (Jha et al., 2017). When employees do not follow written standards of the organization, their behavior impedes the organization's ability to meet corporate goals, accepting employee EB at work is important (Askew et al., 2015).

Hence, scholars have shown an increased interest in 'employee ethical/unethical behavior' since early 1980s, and have generated insights on many positive employee and organizational outcomes. (Trevino, Weaver \& Reynolds, 2006). The ethical context in an organization positively influences ethics-related attitude (commitment) and behavior of employees in the organization (Trevino, Butterfield \& McCabe, 1998). According to Sen and 
Bhattacharya (2001), the perceptions of ethical or socially responsible behavior in an organization could positively influence customer purchase behavior. Ethical image or reputation has been valued as one of the key attributes of a company's ability to attract and retain talent (Foote \& Ruona, 2008). Baker, Hunt and Andrews (2006) identified that Corporate Ethical Values direct employee EB in organizations, and higher the EB, higher the employee performance of Organizational Citizenship Behavior (OCB). They also found that the increased OCB due to enhanced EB may result in higher organizational performance. Thus, "Organizations need employees to behave ethically to produce positive outcomes that are beneficial" (Askew et al., 2015, p. 107). However, managing employee EB at work is a great challenge faced by organizations, locally as well as globally.

Despite many positive consequences of employee EB, growing unethical behavior of employees in business organizations and its negative impact on the organization, economy and the society has become a global concern over the past two decades (De Silva and Opatha, 2015). For more than 30 years researchers have tried to understand why employees behave unethically at work (Kish-Gephart et al., 2010). Unethical behavior of employees violates the generally accepted moral norms, increasing the risks of high-cost burdens to the company (Kaptein, 2011). Immoral behavior of employees challenges the ethical nature of business organizations, drawing immediate attention for more innovative theoretical and empirical research on organizational ethics (De Silva and Opatha, 2015).

The financial giants world over have not been immune to this problem. The financial crisis of 2007 in the West is a notable example of serious negative consequences of unethical behavior of employees in large global banks (Curtis, 2008). Finch (2017) reported that according to data from Boston Consulting Group, banks globally have paid $\$ 321$ billion in fines since 2008 for consequences of many corrupt business practices and unethical behavior of employees. Banks world over, face a great challenge in generating, maintaining and retaining ethical employees at work, due to high competitiveness in the banking industry and rapid technological changes, such as digitization. Organizations are highly concerned about employee unethical behavior due to its many negative consequences (Askew et al., 2015). Decrease in organizational performance, financial losses, damage to the corporate image/reputation, loss of public trust and confidence, loss of customers and market share, financial losses due to lawsuits are few examples of such negative consequences. The 'Asia-Pacific Fraud Survey-2017' by Earnest \& Young had revealed alarming ethical lapses in business organizations in the Asia-Pacific region, where Sri Lanka is also a member country. Growing corrupt business practices and employee unethical behavior justify leading scholars and professionals to review what is being done and create new strategies to manage ethics in organizations (Palomino and Martínez, 2011). Authors conducted this research in the banking industry of their home country, Sri Lanka, due to many motivational factors.

\subsection{Problem Context and Significance of the Study}

The banking industry of a country plays a significant role in growth and sustainability of its national economy. The Banking Sector in Sri Lanka is of no exception. It comprised of 25 Licensed Commercial Banks (LCBs: 13 domestic and 12 foreign) and seven Licensed Specialized Banks (LSBs), with a total of 6659 bank branches and outlets operating island-wide, as of December 31, 2016 (The Central Bank of Sri Lanka, Annual Report 2016, p. 245). The Banking Industry in Sri Lanka accounted for $68.7 \%$ of the total assets of the Financial Sector by end 2016 and the LCBs accounted for the majority of the assets (51\%). Banks do business with public money, thus depend on public trust and confidence for the growth and stability of their business. The employee EB is crucial for banks to establish and maintain an ethical image in the society. Ethical/unethical behavior of employees in local banks have a strong indirect impact on the growth and sustainability of the national economy. Hence, enhancing employee ethicality towards EB at work in banks is vital for the growth and stability of the Banking Sector and the national economy of Sri Lanka.

The Banking Sector in Sri Lanka had grown rapidly over the past two decades, increasing the number of new banks (domestic and foreign) and branches/service outlets of the banks (The Central Bank of Sri Lanka/ Annual Report 2016). The rapid growth in the local banking industry and technological advancements towards digitization, have intensified the competition among banks. The intense competition among players in the financial market had increased challenges and risks to banks, exposing their employees for unethical practices/behaviors to achieve growth targets. The local media had highlighted such incidents of corrupt and unethical behavior of employees in banks operating in Sri Lanka over the past two decades: the collapse of the Pramuka Savings and Development Bank in 2002; the Standard Chartered Bank, Colombo branch hedging transaction with the Ceylon Petroleum Corporation (CPC) amounting to US \$800 million in 2008 (Sunday times.lk/August 2, 2009); the 'white-collar' crime in HSBC Bank, Colombo branch, where five senior managers 
were sacked after investigations into allegations of unethical behavior at work (sundaytimes.lk/June 19, 2016) are few notable examples.

At present, the banks in Sri Lanka do not explicitly embed ethical criteria into their HRM functions and direct them as a 'bundle' to enhance employee ethicality towards EB at work. Instead, banks use a few selected HRM functions, such as recruitment, induction, training \& development in isolation to promote values of banks and EB among employees. There are no theoretical or empirical research that have been conducted in Sri Lanka to explore the impact of EOHRM towards employee EB in the banking industry. The authors identified this as a vital contextual and an empirical research gap. The study extended the existing knowledge frontier and bridged this research gap contributing to the existing knowledge in literature with significant practical/managerial implications.

\subsection{Extending the Existing Knowledge Frontier}

In this study, the authors extended the existing knowledge based on key research gaps identified in previous literature on the link: HRM functions and employee EB. Early researchers have identified many factors that influence employee EB. For instance, Situational-Individual interaction model by Trevino (1986, p. 603) examined the influence of individual cognitions (stage of cognitive moral development) on ethical/unethical behavior of employees. In this model, Trevino (1986) proposed two sets of moderating factors: (i) individual factors and (ii) situational factors. Ferrell and Gresham (1985, p. 89) recommended a contingency framework for marketers for ethical/unethical behavior which examined the influence of (i) Individual factors, (ii) Significant others and (iii) Opportunity for action. Jones (1991) proposed an 'Issue-Contingent' model named 'Moral Intensity Model.' This Model examined the 'intensity' of a moral situation, or the characteristics of the issue itself which influenced ethical decision-making and behavior. In a recent empirical study conducted in Sri Lanka, the researchers (Samaranayake \& Jayasena, 2012) found that bankers' attitude and personal normative beliefs significantly explained their intention to behave ethically/unethically in an information technology context. Dessler (2013) and Opatha (2015) suggested that factors such as moral awareness, managers themselves, moral engagement, morality, unmet goals, rewards etc. would influence employee EB. In a recent meta-review, Lehnert et al., (2015) had summarized results of over 400 empirical research conducted on individual ethical decision-making and behavior over the past three decades. The researchers of this study recommended that more future research is needed on interaction effects (e.g., moderators and mediators) on ethical decision-making and behavior in organizations, as only $8 \%$ of the total studies they reviewed had explored such effects.

Research on HRM in promoting ethics and EB in organizations have become a vital research domain as HRM practices are believed to have a heavy influence on employee behavior (Palomino \& Martinez, 2011). The influence of HRM on employee EB totally depends on the standing of HRM functions in the organization (Foote, 2001). HRM functions play a proactive role in building an ethical culture and climate in the organization (Parboteeaha et al., 2014). Researchers have argued that HRM has an ethical dimension. Thus HRM functions should be ethically oriented. However, the focus of ethical orientation of HRM in the previous literature is on the social/wellbeing of the employee (Winstanley and Woodall, 2000; Greenwood, 2013). That is to perform HRM functions ethically towards the social/wellbeing of the employees. The previous empirical literature does not discuss how ethical orientation of HRM could be used to enhance ethicality of employees towards employee EB at work. Further, the influence of mediating or moderating factors on employee ethical decision-making and behavior also has not been explored in previous studies (Lehnert et al., 2015). The authors identified a vital theoretical, empirical and contextual research gap in existing literature. In order to bridge this knowledge gap to a certain extent, the authors present this paper based on a recent empirical study on the influence of EOHRM on employee EA and EB of employees in commercial banks operating in Sri Lanka. This is an original contribution to the existing knowledge in HRM-ethics literature.

Ethical Orientation of HRM (EOHRM) is a new concept in HRM literature (De Silva \& Opatha, 2015). It has been defined as "the extent to which HRM functions have been directed to create, enhance and maintain ethicality within employees, to generate an ethical workforce in the organization (De Silva, Opatha \& Gamage, 2016, p. 156)." This has been considered as the working definition for EOHRM in this study. EOHRM has also been explained as 'the bundle' of ethical criteria embedded HRM functions directed towards enhancing employee EB in organizations (p. 156). The influence of EOHRM on employee EA and employee EB at work has not been examined empirically, specifically in Sri Lanka and perhaps globally. The present study attempted to bridge the above knowledge gaps to a significant extent by exploring EOHRM towards employee EA and EB. The study has significant originality and vital managerial implications. Directions for future research in HRM-ethics and Organizational Behavior are also discussed. 
Based on the above research gaps in literature, three specific research questions have been developed:

(i) What is the impact of Ethical Orientation of HRM (EOHRM) on employee EB in organizations?

(ii) What is the influence of Ethical Orientation of HRM (EOHRM) on employee EA towards employee EB in organizations?

(iii) How would employee EA mediate the relationship between EOHRM and employee EB in organizations?

The authors developed three specific research objectives to address the above specific research questions:

(i) To empirically investigate the impact of EOHRM on employee EB in organizations.

(ii) To empirically examine the influence of EOHRM on employee EA in organizations.

(ii) To empirically explore the mediating effect of employee EA on the relationship between EOHRM and EB of employees in organizations.

\section{Literature Review}

\subsection{Ethical Orientation of HRM (EOHRM)}

The role of ethics in HRM is a critical factor. Thus HRM functions should have an ethical orientation (Winstanly \& Woodall, 2000; Dessler, 2013; Khan, 2014). The focus of ethical orientation of HRM in previous literature and the long-standing scholarly debate on 'Ethics-HRM' is on the 'social/wellbeing' aspect of the ethical dimension of HRM (Winstanly and Woodall, 2000; Greenwood, 2002; Wright \& Snell, 2005; Greenwood 2013). This is to perform HRM functions ethically in organizations to maintain justice, fairness and well-being towards employees. In contrast to the above conventional view, De Silva, Opatha \& Gamage (2016) identified that there exists a possible second connotation to the ethical dimension of HRM, labeled Ethical Orientation of HRM (EOHRM). The researchers defined EOHRM as "the extent to which HRM functions have been directed to create, enhance and maintain ethicality within employees to generate an ethical workforce in the organization (De Silva et al., 2016, p. 156)." In other words, EOHRM has been defined as 'the ethical criteria embedded HRM functions directed as a 'bundle' to enhance ethicality within employees towards EB in organizations (p. 156). This process involves functional incorporation of ethics into the HR system/framework. This is in contrast to performing HRM functions ethically towards employee 'social/well-being' in organizations. Hence, EOHRM differs from the 'social/wellbeing' aspect of the ethical dimension of HRM, and is a new concept in HRM literature. Authors considered the above definition of EOHRM in De Silva et al. (2016, p. 156) as the working definition of this study.

\subsection{Employee Ethical Behavior (EB)}

There is no universally accepted definition for employee EB. According to Sims (1992, p. 506), EB is a concept which is "morally accepted as good and right, as opposed to bad or wrong in a particular setting." Treviño et al. (2006, p. 952) defined EB as "the individual behavior that is subject to or judged according to generally accepted moral norms of behavior." Further, employee EB has been referred to as the study of ethical and unethical decision-making and behavior in an organization, especially in a work context" (Trevino et al., 2014, p. 6.1). Based on the scholarly definitions in the existing literature, a working definition for employee EB for this study has been developed: Ethical Behavior is to act in ways consistent with what society and self usually think are morally accepted as 'good' and 'right', as opposed to 'bad' or 'wrong'behavior in a particular situation.

In their meta-review, Kish-Gephart et al. (2010) have noted that Rest Model (1986) has guided most of the previous research on behavioral ethics in organizations. The Rest Model (1986), as cited in Kish-Gephart et al. (2010), determined four stages of ethical decision-making and behavior: (i) moral sensitivity (awareness and interpretation of the moral problem); (ii) moral judgement (decision-making ability to distinguish right from wrong); (iii) moral motivation (prioritizing moral values) and (iv) moral character (courage, persistent, and strength of character). Further, employee EB is the outcome of four integrated psychological sub-processes: ethical sensitivity, ethical judgement, ethical motivation and ethical action (Rest, 1986, cited in Bebeau, 2002). Accordingly, authors too operationalized employee EB in this study under four dimensions: (i) ethical sensitivity, (ii) ethical judgement, (iii) ethical motivation and (iv) ethical action.

\subsection{Employee Ethical Attitude (EA)}

Opatha (2015) recognized that "every human being has attitudes which have a significant impact on his/her behavior" (p. 74). Hence, to understand the concept of 'ethical attitude' it is essential to first understand the concept 'attitude.' Scholars have explained 'attitude' in many ways: Dunham (1984) identified that every attitude has three distinct components: cognitive, affective, and behavioral tendency. Robbins et al. (2014) stated that an 
attitude comprised of three components: (i) cognitive (evaluation), (ii) affective (feeling) and (iii) behavioral (action). Ethical attitude thus, invariably means 'an attitude with regard to ethics.' The 'object' of attitude here is 'ethics.' Recent scholars have defined 'ethics' as moral beliefs and rules or obligations about right and wrong (Opatha, 2010; Opatha \& Teong, 2014). Accordingly, authors logically believed that EA has three components: (i) cognition or ethical evaluation, (ii) affect or ethical feelings and (iii) behavioral or intention to behave ethically towards the object 'ethics.' Based on existing scholarly arguments, authors developed a working definition for EA for this study: Ethical Attitude is a psychological concept that shows how an employee thinks, feels and tends to behave with regard to ethics. It may be positive, negative or indifferent. Hence, authors considered EA as a concept that consists of three dimensions: (i) beliefs (cognitive), (ii) feelings (affective) and (iii) intention to behave (behavioral) with regard to ethics.

\section{Conceptual Model}

An integrated, three-construct Conceptual Model was developed based on key research gaps in literature. The three variables identified were: Ethical Orientation of HRM (EOHRM), employee ethical attitude (EA) and employee ethical behavior (EB). The model was empirically tested in LCBs operating in Sri Lanka. The study examined the impact of EOHRM or how ethical criteria embedded HRM functions directed as a 'bundle' would influence employee EA and EB at work. The mediating influence of employee EA on the relationship between EOHRM and employee EB was also examined. The schematic diagram of the Conceptual Model is given in Figure 1.

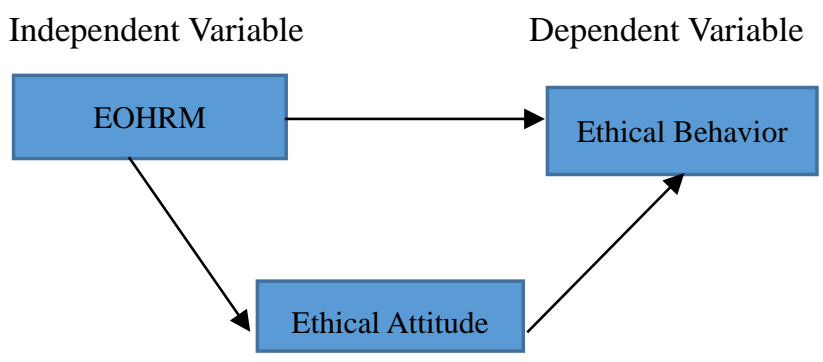

Mediator

Figure 1. Conceptual Model

Source: constructed by the authors

\subsection{Development of Hypotheses}

Based on empirical evidence in existing literature and logical beliefs of the authors, four hypotheses (H1 to H4) were developed through deductive approach, to test the relationships among variables in the Conceptual Model.

\subsubsection{Hypothesis 1, Relating EOHRM to Employee EB}

The standing of HRM functions has a high impact on HRM's ability to influence employee EB (Foote, 2001). Research on HRM in promoting ethics had become a key research topic as HRM practices are believed to have a heavy influence on employees (Palomino \& Martinez, 2011). Dessler (2013) has discussed how HRM functions could promote ethics and EB of employees in organizations. He stated that recruitment materials that emphasize ethics, honesty tests and background checks help to hire more ethical people (p. 467). Further, he argued that in order to promote employee EB at work, "Training should emphasize the moral underpinnings of the ethical choice and company's deep commitment to integrity and ethics (Dessler, 2013, p. 468). Thus, HRM functions have a strong link to employee EB. EOHRM is a new concept and "it is the extent to which HRM functions have been directed to create, enhance and maintain ethicality within employees to generate an ethical workforce (De Silva et al., 2016, p. 156)." Hence, authors logically believed that EOHRM has a strong influence on employee EB in organizations, and hypnotized that EOHRM will significantly and positively influence employee EB in organizations:

\section{$H_{1}$ : EOHRM is positively and significantly related to employee EB in LCBs in Sri Lanka.}

\subsubsection{Hypothesis 2, Relating EOHRM to Employee EA}

Employees' knowledge, skills and attitudes should be complimented with ethical values or moral principles in order to generate, enhance and maintain an ethical workforce in the organization (Savaneviciene \& Stankeviciute, 2012). HRM practices at the organizational level affect the attitude and behavior of employees at the individual level (Paauwe, 2009). Employee EA refers to a psychological contract which shows how an employee thinks, feels and tends to behave with regard to ethics (Rest, 1986, cited in Bebeau, 2002). It is the employee's beliefs, 
feelings and the tendency to behave towards ethics. When the employee's beliefs, feelings and intending to behave towards ethics are optimistic, the employee has a 'positive ethical attitude.' Further, ethical criteria embedded Recruitment and Selection functions ensure that the organization gets the right employees in terms of ethics. In other words, Recruitment and Selection that are concerned with ethicality of job candidates ensure that selected job candidates are people who have a 'positive' pre-disposition or inclination to ethics. Moreover, ethical criteria embedded Induction and Training \& Development functions generate a 'positive attitude' within the employee for proper adherence to ethics. Well-inducted and trained employees on ethics, therefore, expected to have a persistent tendency to believe, feel and behave in a 'positive' manner towards ethics. These logical arguments contributed towards the development of the second hypothesis of the study:

$\boldsymbol{H}_{2}$ : EOHRM is positively and significantly related to employee EA in LCBs in Sri Lanka.

\subsubsection{Hypothesis 3, Relating Employee EA to Employee EB}

Attitudes of individuals have a significant impact on their behavior (Opatha, 2015). Traditional Cognitive Model of attitudes describes attitudes as a process, in which people logically calculate their feelings towards the attitude 'object,' in this position the object being 'ethics.' It is based on an analysis of their beliefs which will predict feelings, behavioral intensions, and behavior (McShane, Glinow \& Sharma, 2008). According to Attitude Behavior Correspondence ( $\mathrm{ABC})$ Model, generally attitudes predict behavior and therefore, attitude and behavior are closely linked (Nelson \& Quick, 1997). The employee who is having a 'positive' attitude to ethics can be expected to engage in 'positive' ethical behavior. Assuming that there are no mediating or moderators influences to cancel the 'attitude-behavior' relationship, it is argued that employee EA influences positively and significantly on employee EB. Accordingly, the third hypothesis of the study H3 was formulated:

\section{$\boldsymbol{H}_{3}$ : Employee EA is positively and significantly related to employee EB in LCBs in Sri Lanka.}

3.1.4 Hypothesis 4, Mediating Impact of Employee EA on the Link: EOHRM and Employee EB

Employee EA (mediating variable) surfaces between the time EOHRM (independent variable) activates to influence employee EB (dependent variable) of the study. Employee EA has a temporal time dimension to EOHRM. Authors believe that the impact of EOHRM on employee EB follows through the employee EA. Thus, on a time line EOHRM operates at time one $\left(\mathrm{T}_{1}\right)$, next the employee EA activates at time two $\left(\mathrm{T}_{2}\right)$ and finally, the employee EB will activate at time three $\left(\mathrm{T}_{3}\right)$. Authors logically believed that the employee EA will help to explain the influence of EOHRM on the employee EB. This logical belief directed towards the final hypothesis of the study:

\section{$\boldsymbol{H}_{4}$ : The relationship between EOHRM and employee EB is significantly mediated by employee EA.}

\section{Methodology}

\subsection{Study Design}

The study examined how EOHRM will influence employee EB through employee EA. The type of investigation was correlational. Primary data were collected at a single point of time. Hence the time horizon was cross-sectional (Sekeran \& Bougie, 2016). The population of the study comprised the total senior and middle level managers working in 11 domestic LCBs operating in Sri Lanka. A stratified random sample of 550 senior and middle level managers was selected from 11 homogeneous LCBs, out of a total of 13 LCBs (The Central Bank of Sri Lanka, Annual Report 2016). A pre-tested, original structured questionnaire (with 5-point Likert Scale) was used to collect primary data, through the respective Human Resource departments of the banks. The researcher's interference on the primary data collection was thus minimal. Authors measured the "observed" behaviors of EA and EB of employees through the senior and middle level managers of respective LCBs, rather than measuring "employees' self-reported" behavior. This minimized the likely social desirability bias error in the study.

\subsection{Instrument and Measures}

The three variables in the Conceptual Model, EOHRM, EA and EB, were measured using multi-item interval scales developed by the authors, and validated prior to final data collection. The variables were carefully conceptualized and operationalized based on previous literature/theories, to develop the individual measurement instruments. The dimensions and elements of variables presented in Table 1 were used to develop the multi-item individual measurement instruments. The elements were used to develop question items, in order to capture primary data from participants. The responses were captured on a 5-point Likert scale, scores ranging from 1 to 5 as strongly disagree (1), disagree (2), neither agree nor disagree (3), agree (4) and strongly agree (5), respectively. 
Table 1 gives the dimensions and elements of variables for developing individual measurement instruments.

Table 1. Dimensions and Elements of variables for development of measurement instruments

1) Ethical Orientation of HRM (EOHRM) - 27 Questions

(Sources: Jackson \& Schuler, 1995; Opatha, 2009; Dessler, 2013; Armstrong \& Taylor, 2014; De Silva et al., 2016)

\begin{tabular}{ll}
\hline \multicolumn{1}{c}{ Dimensions } & Elements \\
\hline Acquire & Ethical criteria embedded HR functions: Job Analysis, Recruitment, Selection, Hiring and Induction \\
Develop & Ethical criteria embedded HR functions: Performance Evaluation and Training \& Development \\
Retain & Ethical criteria embedded HR functions: Pay Management, Incentives Management, Welfare \\
& Management, Management of Promotions, Discipline Management and Grievance Management \\
\hline
\end{tabular}

2) Ethical Behavior (EB) - 12 Questions

(Sources: Rest, 1986, cited in Bebeau, 2002; Kish-Gephart et al., 2010; Al-Taweel, 2015)

\begin{tabular}{ll}
\multicolumn{1}{c}{ Dimensions } & Elements \\
\hline $\begin{array}{l}\text { Ethical } \\
\text { Ethical } \\
\text { Judgement }\end{array}$ & Identifying and expressing emotions and Taking perspective of others. \\
$\begin{array}{l}\text { Ethical } \\
\text { Motivation } \\
\text { Ethical Action }\end{array}$ & $\begin{array}{l}\text { Developing Ethical Reasoning skills, Using Codes and identifying judgement criteria, Following ethical } \\
\text { role models in decision-making and Choosing a decision among several possible alternatives }\end{array}$ \\
\hline
\end{tabular}

3) Ethical Attitude (EA) - 6 Questions

(Sources: Opatha, 2015; Armstrong \& Taylor, 2014; Robbins et al., 2014; Opatha, 2010; Opatha \& Teong, 2014)

\begin{tabular}{ll}
\hline \multicolumn{1}{c}{ Dimensions } & Elements \\
\hline Ethical Belief & Cognitive aspects (believing in ethics or showing respect for ethics) \\
Ethical Feelings & Affective aspects (feel for ethics or being positively sensitivity for ethics) \\
Intention to & Behavioral aspects (genuine interest to behave ethically or strong intensions to discourage unethical \\
behave ethically & behavior) \\
\hline
\end{tabular}

Source: Developed by the authors

The Final questionnaire had 45 questions combining the three individual instruments. In addition to the 45 questions, there were eight questions to capture demographic variables of the respondents such as gender, age, highest qualification, designation category etc. The final questionnaire was pre-tested and validated, prior to using in the primary data collection.

\subsection{Instrument Reliability and Validity}

The internal consistency of the three instruments were determined by examining the coefficient alpha values, on the dimensions first and then on the construct, separately (Cronbach, 1951). The instruments had high degree of internal consistency reliability, with Cronbach's Alpha above 0.70 (Nunnaly, 1978). The respective alpha values of the individual instruments were EOHRM (27 items): 0.922; Ethical Behavior (12 items): 0.909 and Ethical Attitude (6 items): 0.908 . In addition, a 'scale validation' procedure was performed through analysis of inter-item correlation, analysis of item-total correlations and factor analysis, to identify any weakly performing items for the respective instruments. Exploratory Factor Analysis (EFA) was performed to ensure uni-dimensionality of the instruments in order to ensure Construct Validity. Under the KMO \& Barett's Test of Sphericity, the three instruments had Kaiser-Meyer-Olkin (KMO) values above .5 ( $p>0.05)$, which ensured that the sample size was adequate to perform the Factor Analysis (William, Onsman \& Brown, 2010). The results of the EFA with Principal Component Analysis (PCA) of the instruments revealed high factor loadings of items ranging from 0.463 to 0.896 . Further, factors together in each individual instrument explained high variances: EOHRM - 61\%; EB $-58.95 \%$ and EA $-69.6 \%$. This ensured that all items in the three individual instruments performed well. Construct Validity of the instruments were established. As there were no weakly performing items, all items in the final questionnaire were retained for the final data analysis.

\subsection{Data Analysis Techniques}

Statistical Package for Social Sciences (SPSS) Version 23.0 was used to analyze the 360 (65\%) usable primary data received. According to methods suggested by Sekeran and Bougie (2016), the data received were coded and cleaned, before the final statistical analysis. This step was necessary to attend to any missing values and outliers to ensure accuracy of the conclusions drawn from the study (Sekeran \& Bougie, 2016). Descriptive statistics of the three main variables and eight demographic variables were obtained. As the correlation tests were parametric, 
data were tested for normality and linearity to satisfy the required conditions reasonably.

The first three hypotheses of the study ( $\mathrm{H} 1, \mathrm{H} 2$ and $\mathrm{H} 3)$ were examining relationships between variables. The Pearson Product-Moment Correlation technique was used to test the linear relationships between the variables in each of these three hypotheses: $\mathrm{H} 1, \mathrm{H} 2$ and $\mathrm{H} 3$. As the formulated alternate hypotheses were directional, the 'one-tail' test was performed. The fourth and final hypothesis, H4, examined the mediating effect of employee EA on the relationship between EOHRM and employee EB. Multiple Regression analysis and procedures recommended by Baron and Kenny (1986) and Frazier, Tix and Barron (2004) were used to test the mediating relationship in hypothesis, $\mathrm{H} 4$.

\section{Results}

\subsection{Demographic Descriptions of the Sample}

The 360 usable responses (65\%) were used in the final data analysis. Responses included $63 \%$ male and $37 \%$ female senior and middle level managers from 11 LCBs. There were $54 \%$ senior managers and $46 \%$ middle level managers. Majority of the managers $(77 \%)$ were above 40 years. Most of the managers had either professional qualifications (34\%) or postgraduate qualification (28\%), and $12 \%$ had both qualifications. Half of the managers $(51 \%)$ had over 15 years of experience in their current banks. This included managers $(25 \%)$ who were with their present bank for over 25 years. Majority of the respondents $(62 \%)$ were from domestic private banks and others were from domestic State banks (38\%). Majority (77\%) of the respondents were from LCBs in business for over 30 years. The balance $20 \%$ was from banks that had been in business for $20-30$ years.

\subsection{Testing of Hypotheses}

The Pearson Product-Moment Correlation technique (one-tail test) was used to test the Hypotheses of H1, H2 and $\mathrm{H} 3$. The regression coefficient values were examined at the significance level of $p<0.01$. The individual statistical results of hypotheses $\mathrm{H} 1, \mathrm{H} 2$ and $\mathrm{H} 3$ are given in Table 2, Table 3 and Table 4, respectively.

5.2.1 Hypothesis H1, Relating EOHRM to Employee EB

Table 2. Correlation between EOHRM and employee EB

\begin{tabular}{lll}
\hline & & Employee EB \\
\hline EOHRM & Pearson Correlation Coefficient & $0.494^{* *}$ \\
& Sig. $(1-$ tailed) & 0.000 \\
& $\mathrm{~N}$ & 360 \\
\hline
\end{tabular}

Source: survey data, 2017

Hypothesis H1 stated that 'EOHRM is positively and significantly related to employee EB in LCBs in Sri Lanka. The statistical results of Pearson Product-Moment Correlation technique indicated a Correlation Coefficient value of $0.494^{* *}$ (sig. at 0.01 ) for this relationship (Table 2). The statistical results justified that there exists a positive and significant relationship between EOHRM and employee EB in LCBs in Sri Lanka. Hence, hypothesis H1 was substantiated. In other words, EOHRM or ethical criteria embedded HRM functions directed as a 'bundle' will positively and significantly influence employee EB in LCBs in Sri Lanka.

\subsubsection{Hypothesis H2, Relating EOHRM to Employee EA}

Table 3. Correlation between EOHRM and employee EA

\begin{tabular}{lll}
\hline & & Employee EA \\
\hline EOHRM & Pearson Correlation Coefficient & $0.432 * *$ \\
& Sig. (1- tailed) & 0.000 \\
& $\mathrm{~N}$ & 360 \\
\hline
\end{tabular}

Source: survey data, 2017

Hypotheses $\mathrm{H} 2$ predicted a positive and significant relationship between EOHRM and employee EA. The results of Pearson Product-Moment Correlation technique indicated a Correlation Coefficient value of $0.432 * *$ (sig. at 0.01 ) for the relationship between EOHRM and employee EA (Table 3). The statistical results justified that there exists a positive and significant relationship between EOHRM and employee EA. The hypothesis $\mathrm{H} 2$ was statistically accepted. This indicated that ethical criteria embedded HRM functions directed as a 'bundle' will positively and significantly influence employee EA in LCBs in Sri Lanka. 
5.2.3 Hypothesis H3, Relating Employee EA to Employee EB

Table 4. Correlation between employee EA and employee EB

\begin{tabular}{lll}
\hline & & Employee EB \\
\hline Employee EA & Pearson Correlation Coefficient & $0.573^{* *}$ \\
& Sig. (1- tailed) & 0.000 \\
& $\mathrm{~N}$ & 360 \\
\hline
\end{tabular}

Source: survey data, 2017

Hypothesis $\mathrm{H} 3$ forecasted a positive and significant relationship between employee EA and EB. The statistical results of Pearson Product-Moment Correlation technique (one-tail test) reported a correlation coefficient value of $0.573 * *$ (sig. at 0.01 ) for the relationship between employee EA and EB (Table 4). Thus, the statistical results substantiated that a positive and significant relationship exists between employee EA and employee EB with a 99\% confidence level. The hypothesis $\mathrm{H} 3$ was statistically established.

\subsubsection{Hypothesis $\mathrm{H}_{4}$, Mediating Impact of Employee EA on the Link: EOHRM and Employee EB}

The hypotheses $\mathrm{H} 4$ in the mediation model was tested using multiple regression technique, as recommended by Frazier, Tix and Barron (2004). The process had four steps: Step 1: to show that there exists a significant relation between predictor and outcome; Step 2: to show that the predictor is related to the mediator; Step 3: to show that the mediator is related to the outcome, and Step 4: to show that the strength of the relationship between predictor and outcome is significantly reduced when the mediator is added to the model.

The statistical results of Step 1 indicated a regression coefficient of the effect of EOHRM (Predictor) on employee EB (Outcome) was 0.439 (sig. p < 0.000). The requirement in Step 1 was met. In Step 2, it was required to establish that EOHRM (predictor) is significantly related to the employee EA (mediator). In order to establish this, regressing employee EA on EOHRM was performed and the regression coefficient value for this relationship was $0.407 * *$ (sig. $\mathrm{p}<0.000$ ). The requirement for mediation in Step 2 was met.

In order to fulfill the requirements in Step 3 and Step 4, employee EB (Outcome) was regressed concurrently on both employee EA (mediator) and EOHRM (Predictor). The regression coefficient value associated with the relationship between employee EA (mediator) and employee EB (Outcome), controlling for EOHRM (Predictor) was 0.540 (sig. p < 0.000). The requirement for mediation in Step 3 was met. The third regression equation also provided an estimate of the relation between EOHRM (Predictor) and employee EB (Outcome) while controlling for employee EA, the mediator. The above statistical results of the four steps are presented in Table 5.

Table 5. Testing the mediator effect of employee EA on the relationship between EOHRM and EB

\begin{tabular}{lll}
\hline Testing steps in the mediation model & B & Sig. \\
\hline Step 1 & $0.439^{* *}$ & 0.000 \\
Outcome: EB & & \\
Predictor: EOHRM & $0.407^{* *}$ & 0.000 \\
Step 2 & & \\
Mediator: EA & $0.540^{* *}$ & 0.000 \\
Predictor: EOHRM & & \\
Step 3 & & \\
Mediator: EA & $0.269^{* *}$ & 0.000 \\
Outcome: EB & & \\
Step 4 & & \\
Outcome: EB (Path C') & & \\
Mediator: EA & & \\
Predictor: EOHRM & & \\
\hline$* * p<.001$. &
\end{tabular}

Source: survey data, 2017

According to Frazier et al. (2004), in a mediation model when path $\mathrm{C}^{\prime}$ is zero there is complete mediation, and otherwise it is a partial mediation. Path $\mathrm{C}^{\prime}$ is the relationship between predictor and outcome in the mediation model. In this study path C' was 0.269 (sig. $\mathrm{p}<0.000$ ). The strength of the relationship between predictor (EOHRM) and outcome (employee EB) got significantly reduced, when the mediator (employee EA) was added to the model. Further, the statistical results indicated that the value of Path $C^{\prime}$ is not zero but 0.269 . The mediation effect of EA on the relationship between EOHRM and EB is thus partial. Hypothesis $\mathrm{H} 4$ was substantiated. The statistical results established that employee EA is a significant partial mediator on the relationship between EOHRM and employee EB in LCBs operating in Sri Lanka. 
The statistical results substantiated the four hypotheses: $\mathrm{H}_{1}, \mathrm{H}_{2}, \mathrm{H}_{3}$ and $\mathrm{H}_{4}$. Statistical relationships among variables in the Conceptual Model were positive and significant at the 0.001 level, as depicted in Figure 2. Hence, the Conceptual Model of the study (Figure 1) has been supported.

$$
\text { Independent Variable (Predictor) Dependent Variable (Outcome) }
$$

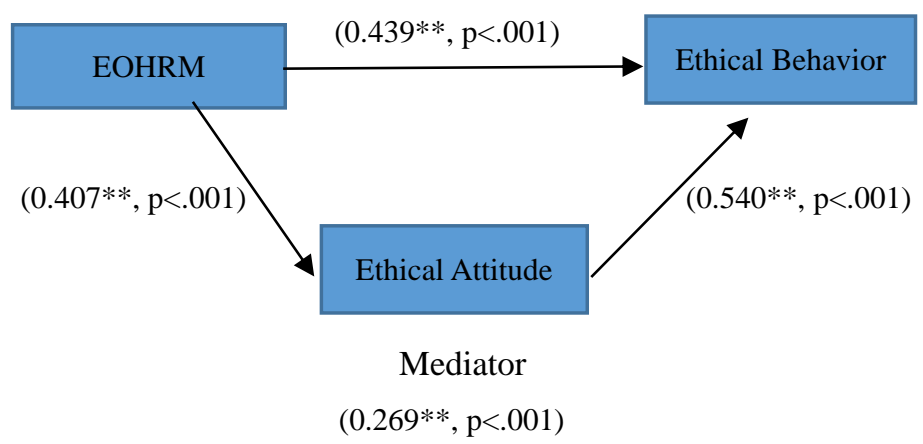

Figure 2. Conceptual Model (mediation): statistical relationships between variables

\section{Discussion and Conclusion}

\subsection{Summary of Findings}

The study developed an integrated original Conceptual Model, formulated four hypotheses (H1, H2, H3 and H4) on hypothetic-deductive approach, and tested empirically in the Sri Lankan banking industry, to address three specific research problems through three specific research objectives:

Objective 1: To empirically investigate the relationship between EOHRM and employee EB (tested through H1).

The statistical results indicated that EOHRM was positively and significantly related to employee EB (Table 2). In other words, ethical criteria embedded HRM functions directed as a 'bundle' positively and significantly influence employee EB in LCBs operating in Sri Lanka.

\section{Objective 2: To empirically investigate the link between EOHRM and employee EA (tested through H2).}

The EOHRM was positively and significantly related to employee EA (Table 3). Thus, ethical criteria included HRM functions positively and significantly influence employee EA in LCBs in Sri Lanka.

\section{Objective 3: To examine the mediating effect of employee EA on the link: EOHRM and employee EB (tested through $\mathrm{H} 3$ and $\mathrm{H} 4$ ).}

The employee EA was positively and significantly related to employee EB (Table 4). The statistical results of the mediation analysis (Table 5) revealed that employee EA significantly and partially mediated the relationship between EOHRM and employee EB $(0.269, \mathrm{p}<.001)$. Employee EA is a significant, partial mediator on the link: EOHRM and employee EB in Sri Lankan LCBs.

\subsection{Originality and Contribution to the Existing Literature}

In contrast to the long-established, existing focus of ethical orientation of HRM on the 'social/wellbeing' aspect of employee, this study empirically explored another facet of the ethical dimension of HRM through ethical orientation or HRM or EOHRM. It is a novel concept in HRM literature, yet to be exposed in theoretical/empirical research (De Silva \& Opatha, 2015; De Silva et al, 2016). The study examined how EOHRM or ethical criteria embedded HRM functions directed as a 'bundle' would enhance employee EA and EB at work. The findings of the study are original. Authors bridged the knowledge gap in literature to a significant extent, by achieving the research objectives.

Further, the Conceptual Model (Figure 1) is an original model that has not been formulated theoretically and tested empirically in previous research, definitely in the Sri Lankan and Asian literature, and perhaps globally. The model has its originality in explaning two important dynamics of employee EB in organizations, i.e., Ethical Orientation of HRM (EOHRM) and employee EA at work. In a recent case study conducted in India (Jha, et al., 2017), the researchers suggested that "the HRS [Human Resource Systems] need to incorporate the ethical dimension in their processes and procedures as they shape the perception of employees about ethical standards of the organization" (p. 21). The present study bridged this critical knowledge gap by empirically examining how EOHRM would impact on ethicality of employees, towards employee EA and EB at work. Further, the authors bridged a vital methodological/contextual gap in literature too, by developing original, validated measurement 
instruments for the constructs EOHRM, employee EA and employee EB in organizations.

\subsection{Managerial Implications}

The results revealed innovative, vital managerial implications, how ethically oriented HRM functions could enhance ethicality within employees, towards employee EA and EB. Further, it was found that employee EA plays a vital role as a mediator on the relationship between EOHRM and employee EB at work. Organizations that wish to ensure their employees behave ethically, first need to enhance employee EA through EOHRM. This is possible by embedding ethical criteria into HRM functions and directing them as a 'bundle', instead of traditionally using one or two individual HRM functions in isolation, such as Induction or Training \& Development, to inculcate ethics into employees. These are hopefully vital managerial implications for the Banking Sector in Sri Lanka, and perhaps globally.

\subsection{Research Limitations and Directions for Further Research}

This study was limited to the banking industry in Sri Lanka, considering the value of the study in the banking context in authors' home country. Authors recommend, future local and global studies should explore ethical orientation of HRM or EOHRM in different study settings: different industries, different organizational settings, different countries, different economic systems and in different time periods of an organization's life cycle. This is a cross sectional study in the time horizon, thus a longitudinal study is recommended to identify any causality among the constructs. Authors followed the quantitative method. Future studies may use qualitative, case study, mixed methods etc., to explore this novel construct: EOHRM. This study examined the influence of only one mediating variable, employee EA, on the relationship between EOHRM and employee EB. In future research, the impact of other mediating and moderating variables, such as individual and situational factors, on the above relationship could be examined.

\section{References}

AL-Taweel, (2015). Developing Rest's Model to Examine the Relationship between Ethical Accounting Education and International Education Standard. International Journal of Business and Social Science, 6(11), 8-17.

Armstrong, M., \& Taylor, S. (2014). Armstrong's handbook of management and leadership: developing effective people skills for better leadership and management. Kogan Page Publishers.

Askew, O. A., Beisler, J. M., \& Keel, J. (2015). Current Trends of Unethical Behavior within Organizations. International Journal of Management \& Information Systems, 19(3), 107-113. https://doi.org/10.19030/ijmis.v19i3.9374

Baker, T. L., Hunt, T. G., \& Andrews, M. C. (2006). Promoting ethical behavior and organizational citizenship behaviors: The influence of corporate ethical values. Journal of Business Research, 59(7), 849-857. https://doi.org/10.1016/j.jbusres.2006.02.004

Baron, R. M. \& Kenny, D. A. (1986). The moderator-mediator variable distinction in social psychological research: Conceptual, strategic, and statistical considerations. Journal of personality and social psychology, 51(6), 1173. https://doi.org/10.1037/0022-3514.51.6.1173

Bebeau, M. J. (2002). The defining issues test and the four component model: Contributions to professional education. Journal of Moral Education, 271-295. https://doi.org/10.1080/0305724022000008115

Cronbach, L. J. (1951). Coefficient alpha and the internal structure of tests. Psychometrika, 16, 297-334. https://doi.org/10.1007/BF02310555

Curtis, G. (2008). The financial crisis and the collapse of ethical behavior. Greycourt White Paper, 44.

De Silva, V. A., \& Opatha, H. H. D. N. P. (2015). Role of ethical orientation of HRM in establishing an ethical organizational culture: A literature review and implications, In 12th International Conference on Business Management (ICBM), December, 2015. https://doi.org/10.2139/ssrn.2699792

De Silva, V. A., Opatha, H. H. D. N. P., \& Gamage, A. S. (2016). Towards Extending the Ethical Dimension of Human Resource Management. International Business Research, 9(10), 151. https://doi.org/10.5539/ibr.v9n10p151

Dessler, G. (2013). Human Resource Management. $13^{\text {th }}$ Ed. Pearson Education Inc., New Jersey: Prentice-Hall.

Dunham, R. B. (1984). Organizational Behavior: People and Processes in Management, Homewood, Illinois: Richard D. Irwin, Inc. 
Ferrell, L. G., \& Gresham, L. G. (1985). A contingency framework for understanding ethical decision making in marketing. The Journal of Marketing, 87-96. https://doi.org/10.2307/1251618

Finch, G. (2017). Bloomberg. https:/www.bloomberg.com/news/articles/2017-03-02/

Foote, D. (2001). The question of ethical hypocrisy in human resource management in the UK and Irish charity sectors. Journal of Business Ethics, 34(1), 25-38. https://doi.org/10.1023/A:1011909904150

Foote, M. F., \& Ruona, W. E. A. (2008). Institutionalizing Ethics: A Synthesis of Frameworks and the Implications for HRD. Human Resource Development Review, 7(3), 292-308. https://doi.org/10.1177/1534484308321844

Frazier, P. A., Tix, A. P., \& Barron, K. E. (2004). Testing moderator and mediator effects in counseling psychology research. Journal of counseling psychology, 51(1), 2004, 115. https://doi.org/10.1037/0022-0167.51.1.115

Greenwood, M. R. (2002). Ethics and HRM: A review and conceptual analysis. Journal of Business Ethics, 36(3), gamage, 261-278. https://doi.org/10.1023/A:1014090411946

Jackson, S. E., \& Schuler, R. S. (1995). Understanding human resource management in the context of organizations and their environments. Human Resource Management: Critical Perspectives on Business and Management, 2, 45-74. https://doi.org/10.1146/annurev.ps.46.020195.001321

Jha, J. K., Varkkey, B., Agrawal, P., \& Singh, N. (2017). Contribution of HR Systems in Development of Ethical Climate at Workplace: A Case Study. South Asian Journal of Human Resources Management, 4(1), 106-129.

Jones, T. M. (1991). Ethical decision making by individuals in organizations: An issue-contingent model. Academy of management review, 16(2), 366-395.

Kaptein, M. (2011). Understanding unethical behavior by unraveling ethical culture. Human relations, 64(6), 843-869. https://doi.org/10.1177/0018726710390536

Khan, M. (2014). Ethical human resource management: a critical analysis, BAM2014, British Academy of Management Conference Proceedings. http://eprints.lincoln.ac.uk/16085/1/Ethical\%20HRM.pdf

Kish-Gephart, J. J., Harrison, D. A., \& Treviño, L. K. (2010). Bad apples, bad cases, and bad barrels: meta-analytic evidence about sources of unethical decisions at work. Journal of applied Psychology, 95(1), 1. https://doi.org/10.1037/a0017103

Lehnert, L., Park, Y. H., \& Singh, N. (2015). Research note and review of the empirical ethical decision-making literature: Boundary conditions and extensions. Journal of Business Ethics, 129(1), 195-219. https://doi.org/10.1007/s10551-014-2147-2

McShane, S. L., Glinow, M. A. V., \& Sharma, R. R. (2008). Organizational Behavior, New York: McGraw-Hill.

Nelson, D. L., \& Quick, J. C. (1997). Organizational Behavior: Foundations, Realities, and Challenges, New York: West Publishing Company.

Nunnaly, J. (1978). Psychometric Theory, 1978, New York: McGraw-Hill.

Opatha, H. H. D. N. P. (2009). Human Resource Management: Personnel. Department of HRM, University of Sri Jayewardenepura, Sri Lanka.

Opatha, H. H. D. N. P. (2015). Organizational Behavior: The Human Side of Work, Department of HRM, University of Sri Jayewardenepura, Sri Lanka.

Opatha, H. H. D. N. P., \& Teong, L. K. (2014). Enhancing Your Personal Q, Kedah Darul Aman: University Utara Malaysia, UUM Press.

Opatha, H. H. D. N. P. (2010). Personal Quality. Department of HRM, University of Sri Jayewardenepura, Sri Lanka.

Paauwe, P. (2009). HRM and performance: Achievements, methodological issues and prospects, Journal of Management studies, 46(1), 129-142. https://doi.org/10.1111/j.1467-6486.2008.00809.x

Palomino, P., \& Martínez, R. (2011). Human resource management and ethical behavior: Exploring the role of training in the Spanish banking industry. Ramon Llull Journal of Applied Ethics, 2, 69.

Robbins, S., Judge, T. A., Millett, B., \& Boyle, M. (2014). Organizational Behavior, Pearson Higher Education AU. 
Samaranayake, G. P. R. G., \& Jayasena, V. S. (2012). Ethical decision making in an information technology context: influences on the bankers in Sri Lanka. In Proceedings of International Conference on Business Management, 8.

Savaneviciene, A., \& Stankeviciute, Z. (2012). HRM and performance linkage: The role of line managers. Economics and Management, 17(1), 390-396. https://doi.org/10.5755/j01.em.17.1.2294

Sekaran, U., \& Bougie, R. (2016). Research methods for business: A skill building approach, John Wiley \& Sons.

Sen, S., \& Bhattacharya, C. B. (2001). Does doing good always lead to doing better? Consumer reactions to corporate social responsibility. Journal of marketing Research, 38(2), 225-243. https://doi.org/10.1509/jmkr.38.2.225.18838

Sims, R. R. (1992). The challenge of ethical behavior in organizations. Journal of Business Ethics, 11(7), 505-513. https://doi.org/10.1007/BF00881442

The Asia-Pacific Fraud Survey (2017). https://fraudsurveys.ey.com/ey-asia-pacific-fraud-survey-2017, accessed 01.11.2017.

The Central Bank of Sri Lanka. http://www.CBSL.lk/Annual Report 2016, accessed 25.01.17

The Sunday Times (August 2, 2016). http://www sundaytimes.lk/August 2, 2016).

The Sunday Times (June 19, 2016). http://www sundaytimes.lk/June 19, 2016).

Trevino, L. K. (1986). Ethical decision making in organizations: A person-situation interactionist model. Academy of management Review, 11(3): 601-617.

Treviño, L. K., Butterfield, K. D., \& McCabe, D. L. (1998). The ethical context in organizations: Influences on employee attitudes and behaviors. Business Ethics Quarterly, 8(03), 447-476. https://doi.org/10.2307/3857431

Treviño, L. K., den Nieuwenboer, N. A., \& Kish-Gephart, J. J. (2014). (Un) ethical behavior in organizations. Annual Review of Psychology, 65, 635-660. https://doi.org/10.1146/annurev-psych-113011-143745

Treviño, L. K., Weaver, G. R., \& Reynolds, S. J. (2006). Behavioral ethics in organizations: A review. Journal of management, 32(6), 951-990. https://doi.org/10.1177/0149206306294258

Victor, B., \& Cullen, J. B. (1988). The organizational bases of ethical work climates. Administrative science quarterly, 101-125. https://doi.org/10.2307/2392857

Williams, B., Onsman, A., \& Brown, T. (2012). A Rasch and factor analysis of a paramedic graduate attribute scale. Evaluation \& the health professions, 35(2), 148-168. https://doi.org/10.1177/0163278711407314

Winstanley, D., \& Woodall, J. (2000). The ethical dimension of human resource management. Human Resource Management Journal, 10(2), 5-20. https://doi.org/10.1111/j.1748-8583.2000.tb00017.x

Wright, P. M., \& Snell, S. A. (2005). Partner or guardian? HR's challenge in balancing value and values. Human Resource Management, 44(2), 177-182. https://doi.org/10.1002/hrm.20061

\section{Copyrights}

Copyright for this article is retained by the author(s), with first publication rights granted to the journal.

This is an open-access article distributed under the terms and conditions of the Creative Commons Attribution license (http://creativecommons.org/licenses/by/4.0/). 